\title{
Expression of angiogenic factors in childhood B-cell precursor acute lymphoblastic leukemia
}

\author{
DANIEL STACHEL ${ }^{1}$, MICHAEL ALBERT ${ }^{2}$, RITA MEILBECK $^{2}$, MARIOS PAULIDES $^{1}$ and IRENE SCHMID ${ }^{2}$ \\ ${ }^{1}$ Department of Pediatrics, Pediatric Hematology and Oncology, University of Erlangen-Nürnberg, Erlangen; \\ ${ }^{2}$ Kinderklinik and Kinderpoliklinik, Dr von Haunersches Kinderspital, Klinikum Innenstadt, \\ Ludwig Maximilians-University Munich, Lindwurmstr. 4, 80337 Munich, Germany
}

Received July 13, 2006; Accepted September 19, 2006

\begin{abstract}
Pathological angiogenesis is increasingly recognized to be an important feature of pathogenesis in solid tumors and also in leukemias. Specific blockers of angiogenesis are now being introduced into early clinical trials with encouraging results. Vascular endothelial growth factor (VEGF) seems to play a central role in tumor angiogenesis and is associated with a poor prognosis in both solid tumors and adult leukemias. In pediatric acute lymphocytic leukemia however, the expression of angiogenic molecules and its relation to prognosis and relapse are unknown. Therefore, we prospectively analyzed 46 pediatric patients with precursor B cell acute lymphocytic leukemia by semi-quantitative RT-PCR for expression of the angiogenic molecules VEGF, VEGF-C, iNOS and TGF- $\beta$ and correlated relapse and survival data with the expression of these factors. We found a high mRNA expression of TGF- 3 and iNOS, a moderate expression of VEGF but no expression of bFGF and VEGF-C. A significantly higher expression of VEGF mRNA was found in patients with late relapses compared to patients without relapses $(p=0.043)$. A significantly higher mRNA expression of iNOS was found in surviving patients compared with non-surviving patients $(\mathrm{p}=0.023)$. Angiogenic factors are expressed in the bone marrow of patients with pediatric B cell precursor ALL and VEGF is a potential candidate for therapeutic intervention as it is significantly higher expressed in children with late relapses. The mRNA expression of iNOS in the surviving children possibly reflects an increased activity of the immune system against the leukemia which leads to a superior survival.
\end{abstract}

\section{Introduction}

Pathological angiogenesis is increasingly recognized to be an important feature in the pathogenesis of solid tumors (1-3).

Correspondence to: Dr Daniel Stachel, Klinik mit Poliklinik für Kinder und Jugendliche, Friedrich-Alexander Universität ErlangenNürnberg, Loschgestrasse 15, D-91054 Erlangen, Germany

E-mail: daniel.stachel@kinder.imed.uni-erlangen.de

Key words: angiogenesis, VEGF, inducible nitric oxide synthase, prognosis, acute leukemia, children
The most important mediators involved in tumor angiogenesis are members of the vascular endothelial growth factor (VEGF) family, basic fibroblast growth factor (bFGF), transforming growth factor $\beta$ (TGF- $\beta$ ) and nitric oxide (NO) produced by the inducible NO synthase (iNOS) (4-8). VEGF has been shown to be essential in neoplastic angiogenesis (4). The members of the VEGF family consisting of VEGF-A, VEGF-B, VEGF-C, VEGF-D, VEGF-E and placental growth factor (PIGF) have different activities on blood or lymphatic vessels and different receptors $(9,10)$. Pathological angiogenesis has also been described in hematological malignancies such as AML, B-CLL and ALL (11-13) in adult patients. Pathological angiogenesis here is mainly induced by VEGF and, inconstantly, by bFGF $(4,13,14)$. VEGF-C has been shown to synergize with VEGF and bFGF (15) and to mediate proliferation, survival and resistance to chemotherapy in human leukemia cell lines and in patient samples (16).

It has been shown that the expression of these mediators of angiogenesis, especially VEGF and bFGF in cancer patients is associated with an adverse prognosis (17-19). Not only in solid tumors but also in different leukemias the expression of these mediators carries an adverse prognosis (12,20-22). In pediatric ALL only an increased microvessel density histologically in the bone marrow and an elevated urinary bFGF level have been reported (23), but no studies have so far addressed the question of expression of angiogenic factors. This led us to the prospective evaluation of these angiogenic factors and their predictive value for relapse and survival in a pediatric ALL population.

In the last few years, many molecules which block pathological angiogenesis by different mechanisms have been discovered and early clinical trials with these agents are ongoing with promising results (reviewed in refs. 10,14,24). Thalidomide and its analog, lenalidomide, arsenic trioxide, farnesyl transferase inhibitors (tipifarnib and lonafarnib) and matrix metalloprotease (MMP) inhibitors (prinomastat) are angiogenesis antagonists acting on different stages of the angiogenic process. Blockade of angiogenic receptor signaling by receptor tyrosine kinase inhibitors [e.g. sorafenib, sunitinib (SU11248), SU5416 or vatalanib] or monoclonal antibodies neutralizing VEGF (e.g. Bevacizumab) represents a more specific way to inhibit angiogenesis. A number of angiogenesis inhibitors are now in clinical trials in patients with hematological and solid tumors $(10,25-31)$. This indicates the clinical 
Table I. Semi-quantitative expression of mRNA of bone marrow mononuclear cells of pediatric ALL patients.

\begin{tabular}{lcccccccc}
\hline Signal & TGF- $\beta$ & iNOS & VEGF & VEGF-C & bFGF & GAPDH & ß-actin & neg Co \\
\hline Mean \pm SD & $1.40 \pm 0.80$ & $1.34 \pm 0.74$ & $0.62 \pm 0.55$ & $0.00 \pm 0.00$ & $0.02 \pm 0.16$ & $1.91 \pm 0.35$ & $1.80 \pm 0.48$ & $0.00 \pm 0.00$ \\
Median & 2.0 & 1.75 & 0.5 & 0.0 & 0.0 & 2.0 & 2.0 & 0.0 \\
Negative patients (\%) & $15.2 \%$ & $10.5 \%$ & $31.6 \%$ & $100 \%$ & $97.6 \%$ & $2.2 \%$ & $0 \%$ & $100 \%$ \\
$\mathrm{n}$ & 46 & 38 & 38 & 10 & 41 & 46 & 42 & 46 \\
\hline
\end{tabular}

Semi-quantitative expression of mRNA in bone marrow mononuclear cells of pediatric ALL patients. Mean TGF- $\beta$, iNOS, VEGF, VEGF-C, bFGF, GAPDH and B-actin expression levels. Intensity of expression was semi-quantitatively observed (level 0-2). Median of expression level, percentage of patients not expressing the respective mRNA and total number of patients analysed are also given.

significance of this study for identifying possible therapeutic targets in childhood B cell precursor ALL.

Therefore, we examined the expression of VEGF, VEGF-C, bFGF, iNOS and TGF- $\beta$ by semi-quantitative RT-PCR in the bone marrow cells of children with B cell precursor ALL and correlated the expression of those molecules with the clinical outcome. We found a high mRNA expression of TGF- $\beta$ and iNOS, a moderate expression of VEGF but no expression of bFGF and VEGF-C. A significantly higher expression of VEGF mRNA was found in patients with late relapses compared to patients without relapses. A significantly higher mRNA expression of iNOS was found in surviving patients compared with non-surviving patients.

\section{Patients and methods}

Patients. Bone marrow aspirates of 46 consecutive children referred to our center with untreated CD10-positive B cell precursor ALL were analyzed prospectively at initial diagnosis. There were 27 males and 19 females with a mean age of $6.1 \pm 4.0$ years (median, 4.8 years; range, 1.1-15.6 years). Patients were followed for relapse and survival for the duration of the study. The mean observation time was $41.8 \pm 24.1$ months (median, 34.8 months; range, 0.5-94.5 months). Observation time (in months) was defined as the interval between date of diagnosis and date of last follow-up, date of death or date of the end of the study, respectively, whichever came first.

A very early relapse (VER) was defined as a relapse within 18 months after diagnosis. The control group consisted of children with ALL without relapse with an observation period of $>18$ months after diagnosis (30 patients). An early relapse (ER) was defined as a relapse between 18 and 30 months after diagnosis. As a control group patients with an observation period of $>30$ months from the time of diagnosis who did not relapse were recruited (23 patients). A late relapse (LR) was defined as a relapse $>30$ months after diagnosis. As a control group patients with an observation period of $>45$ months after diagnosis who were still in first complete remission (no relapse) were used (11 patients).

Patients were treated according to the national CoALL protocol (32). Written informed consent was obtained from the parents or guardians of the children.

Bone marrow processing, incubation, mRNA preparation and cDNA synthesis. Bone marrow samples were drawn by aspiration from the iliac crest into a heparinized syringe. Bone marrow mononuclear cells were enriched by Ficoll density gradient centrifugation. Mononuclear cells $\left(5 \times 10^{5}\right)$ were suspended in Chomczynski solution (guanidin thiocyanate, sodium citrate, sarcosyl, mercapto ethanol) after washing with RPMI-1640/10\% FCS without prior incubation. Total cellular RNA was prepared according to the method described by Chomczynski (33).

For cDNA-synthesis reverse transcription was carried out using $\mathrm{p}(\mathrm{dT}) 15$ Primer (Boehringer Mannheim) and AMV reverse transcriptase (Boehringer Mannheim) as recommended by the manufacturer. cDNA was stored frozen at $-20^{\circ} \mathrm{C}$ until use.

$R T-P C R$. Primers were either purchased or were custom synthesized by MWG Biotech, Ebersberg, Germany. Primers for TGF- $\beta, \beta$-actin and GAPDH were purchased from Stratagene, La Jolla, CA, USA, primers for VEGF-C were from R\&D Systems, Mineapolis, MN, USA and primers for iNOS were from BD Biosciences Clontech, Palo Alto, CA, USA.

Sequences of the synthesized primers for bFGF and VEGF were modified from published sequences: $\mathrm{bFGF}$, sense primer 5'-AGCAGAAGAGAGAGGAGTTGTGTC-3', antisense primer 5'-CCCAGGTCCTGTTTTGGATCCAAG-3', 232 bp, modified based on Hussong (34); VEGF, sense primer 5'-TC GGGCCTCCGAAACCATGAACT-3', antisense primer 5'TCCTGGTGAGAGATCTGGTTCCC-3', 651 bp, modified based on Fiedler (35).

Each PCR assay was performed in a $100-\mu 1$ reaction tube containing $5 \mu 1$ 10X TAQ buffer, $5 \mu 1$ sense primer $(10 \mu \mathrm{M})$, $5 \mu \mathrm{l}$ antisense primer $(10 \mu \mathrm{M}), 2.5 \mu \mathrm{d} \mathrm{dNTP}(1.25 \mathrm{mM}), 0.2 \mu \mathrm{l}$ TAQ polymerase ( $5 \mathrm{U} / \mu 1$, Perkin Elmer, Norwalk, CT, USA, or Boehringer Mannheim), $30.3 \mu \mathrm{l}$ Aqua dest. and $2 \mu \mathrm{l}$ cDNA equivalent of 12,500 cells. When using commercial primers the volume and concentration of the primers as recommended by the manufacturer were used.

PCR was performed using a DNA Thermal Cycler 480 (Perkin-Elmer) with the following conditions: initial denaturation for $5 \mathrm{~min}$ at $94^{\circ} \mathrm{C}$, followed by $5 \mathrm{~min}$ at $60^{\circ} \mathrm{C}$. Cycle times and temperatures were $90 \mathrm{sec}$ at $72^{\circ} \mathrm{C}, 45 \mathrm{sec}$ at $94^{\circ} \mathrm{C}$, $45 \mathrm{sec}$ at $60^{\circ} \mathrm{C}$, for 35 cycles. Final elongation was $5 \mathrm{~min}$ at $72^{\circ} \mathrm{C}$. A negative and two positive controls (GAPDH and $\beta$-actin) were included in each experiment.

The PCR products were run in a $1.5 \%$ SeaKem LE agarose gel (FMC Bioproducts, Rockland, ME, USA) and stained with ethidium bromide at a final concentration of $0.5 \mu \mathrm{g} / \mathrm{ml}$. 
A

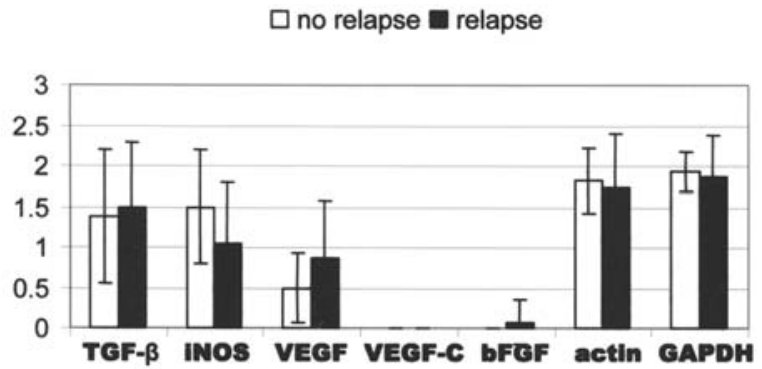

B

$\square$ No VER $\square$ VER

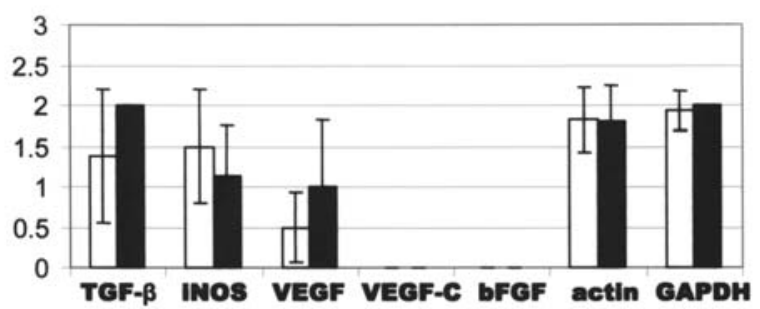

C

$\square$ no ER $\mathrm{EER}$

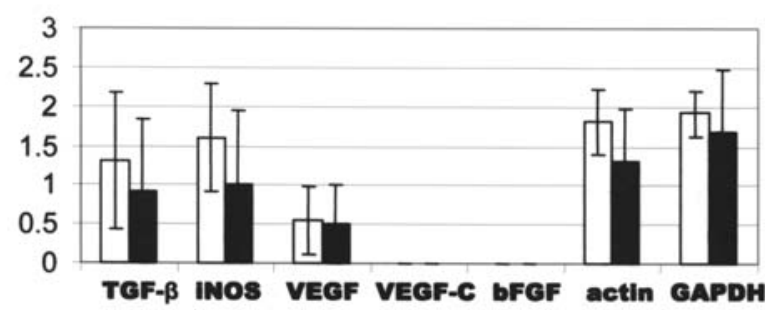

The intensity of the PCR products was evaluated semiquantitatively by two observers. Ratings were negative (0), poorly visible (0.5), fairly visible (1) and strongly visible (2).

Statistical analysis. Normal distribution was examined using the Kolgorov-Smirnow test. If the data were normally distributed the two-tailed Student's t test was used, otherwise the Mann-Whitney U test was used. A difference was considered significant if the two-tailed probability was less than 0.05. All statistics were calculated using the SPSS for Windows software package, version 10.0 (SPSS Inc., Chicago, IL, USA).

\section{Results}

Clinical outcome of study patients. Of the 46 patients in the study, $30(65.2 \%)$ remained relapse-free. Relapse was observed in 15 patients: 5 had a very early relapse (VER), 6 an early relapse (ER) and 4 a late relapse (LR). Overall survival was $82.6 \%$ (38/46 patients). One patient died during induction therapy from infection and therefore was not included in the relapse analysis. Seven children died related to leukemia: four with VER, two with ER and one with LR.

These results compare well with those reported in the literature for childhood BPC ALL (32).

Transcription of mRNA in bone marrow cells of pediatric patients with B cell precursor acute lymphoblastic leukemia.
D

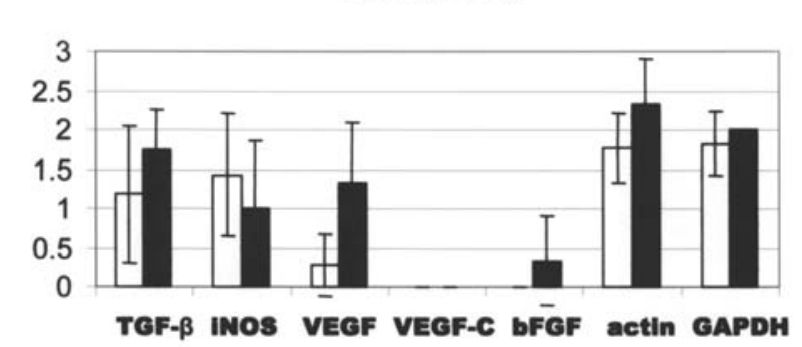

$\mathbf{E}$

$\square$ surviving patients $\quad$ deceased patients

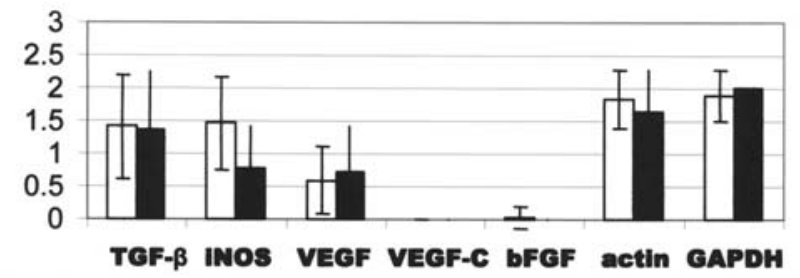

Figure 1. Expression of different angiogenic factors in marrow cells of children with B cell precursor ALL by RT-PCR. RT-PCR for different angiogenic factors was performed in bone marrow cells of children with B cell precursor ALL and the PCR product was graded according to intensity from 0 (no band visible) to 2 (strong band). Patient groups were separated according to the occurrence of relapses or to survival status. "Significant difference, $\mathrm{p}<0.05$, between the two patient groups. VEGF, vascular endothelial growth factor; bFGF, basic fibroblast growth factor; iNOS, inducible NO synthase; TGF- $\beta$, transforming growth factor- $\beta$; BCP-ALL, B cell precursor acute lymphoblastic leukemia; VER, very early relapse; ER, early relapse; LR, late relapse.

To investigate the expression of angiogenic molecules in the bone marrow of children with B cell precursor ALL we performed RT-PCR on bone marrow cells for TGF- $\beta$, iNOS, VEGF, VEGF-C and bFGF. GAPDH and $B$-actin served as positive controls (Table I).

For TGF- 3 and iNOS a high level of expression was found with strong positive signals (median $\geq 1.5$ relative intensity) in 28/46 (61\%) and 20/38 (53\%), respectively. For VEGF an intermediate level of expression was found (median 0.5 relative intensity). No positive signals for VEGF-C and only a single positive signal for bFGF were observed.

We detected mRNA for TGF- $\beta$, iNOS and VEGF in the majority of samples but not for VEGF-C or bFGF.

Differences in the expression of $m R N A$ between different relapse groups. The second aim of this study was to identify possible implications of positive mRNA expression of angiogenic mediators on the clinical outcome of the patients. Comparing patients who relapsed (irrespective of duration of remission) with those who stayed in remission we found no significant difference in the expression of angiogenic factors (Fig. 1). When analyzing subgroups of patients according to the length of remission we found that patients with a very early relapse (VER, first relapse within 18 months after diagnosis) or an early relapse (ER, first relapse between 18 and 30 months after diagnosis) showed no significant differences for any variable compared with relapse-free patients (Fig. 1b and c). Patients with a late relapse (LR, first relapse $>30$ months 


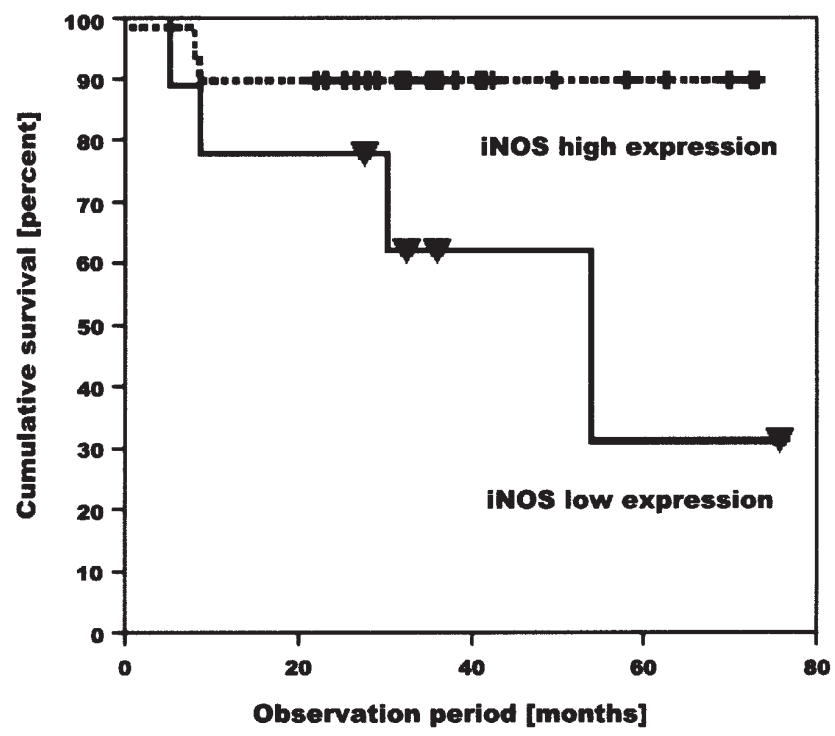

Figure 2. Kaplan-Meier plot of survival for different iNOS mRNA intensities. Patients were grouped according to the relative intensity of iNOS expression. Patients showing a relative intensity of 1 to 2 for iNOS were classified as iNOS high intensity (dashed line, $\mathrm{n}=29$ ) and compared to patients showing a relative intensity of 0 to 0.5 (classified as iNOS low intensity, solid line, $n=9$ ).

after diagnosis) showed significantly increased expression of cytokine RNA for VEGF [1.33 \pm 0.76 (median 1.5) vs $0.29 \pm 0.39$ (median 0.0), $\mathrm{p}=0.043$ ] compared with patients staying in remission. For TGF- $\beta$, iNOS, VEGF-C and bFGF no statistical difference was found (Fig. 1d). We identified increased expression of VEGF mRNA as a unique feature of children suffering from a late relapse.

High intensity expression of iNOS was a significant indicator for survival. Patients who survived showed a significantly increased expression of iNOS $[1.47 \pm 0.71$ (median 2) vs $0.79 \pm 0.64$ (median 0.5), $\mathrm{p}=0.023]$ compared with the deceased patients (Fig. 1e). Kaplan-Meier analysis (Fig. 2) showed a survival of $33.1 \%$ (SE 0.237 ) with a survival time of 46.6 months (95\% CI: 27.3-65.9 months) for those nine patients who showed a low intensity signal (relative intensity of 0 or 0.5 ) for iNOS compared to a survival of $89.7 \%$ (SE 0.057) with a survival time of 65.9 months (95\% CI: 58.5-73.4 months) for those 29 patients who showed a high intensity signal (relative intensity of 1 to 2 ) for iNOS. For the other molecules no difference was found.

\section{Discussion}

In contrast to adult hematological malignancies, the expression of angiogenic molecules in pediatric B cell precursor acute lymphocytic leukemia and its relation to prognosis and relapse are unknown. In children in only one study (23) an increased microvessel density points indirectly to an ongoing angiogenesis, the mediators of which are unknown. Since specific blockers of angiogenesis are now being introduced into early clinical trials with promising results it appears mandatory to establish which angiogenic factors are present in pediatric ALL. We therefore prospectively examined bone marrow cells of children with B cell precursor ALL by RT-PCR.
We found a high expression of TGF- 3 and iNOS mRNA, a moderate expression of VEGF mRNA, but no signals for VEGF-C and bFGF in the bone marrow of children with $B$ cell precursor ALL. TGF- $B$ not only has immunosuppresive action but also directly stimulates angiogenesis; an effect which can be blocked by antibodies against TGF- $\beta(6,36)$. Increased levels of TGF- $\beta$ can be found in the majority of solid tumors and leukemias in adults $(37,38)$. Expression of iNOS has been reported only in AML and B-CLL but has so far not been investigated in ALL patients $(39,40)$. In adult hematological malignancies VEGF and bFGF are the most important mediators of angiogenesis $(10,13)$ and elevations of VEGF and bFGF plasma levels were described in AML, CML (41) and B-CLL. We found moderate expression of VEGF. Elevated plasma levels of bFGF and normal plasma levels of VEGF in adult ALL were found by Aguayo (13). Elevated urinary bFGF levels have been reported in pediatric ALL patients (23).

We found no bFGF expression in marrow cells in the children with BCP-ALL in the present study. A number of leukemia cells produce bFGF $(42,43)$. However, bFGF is produced mainly by stroma and sometimes by endothelial cells (44) which are not frequently encountered in Ficoll separated marrow aspirates. It can therefore be concluded that the elevated bFGF levels are not derived from the blast cells but probably from stimulated stroma or endothelial cells. Only scarce data exist on the expression of VEGF-C. Fiedler et al described the expression of VEGF-C in 8 of 13 adult AML patients tested (45) and Salven et al reported its expression by lymphoma cells (46). To conclude, angiogenic factors are present in pediatric ALL, but it seems that the mediators differ from that in adult haematological malignancies.

Patients with a late relapse showed a higher expression of VEGF mRNA than the control group (children with ALL but without relapse). This trend was also seen in the comparison of all relapses and the VER subgroup but this difference did not reach statistical significance. VEGF is a strong angiogenic factor and also immunosuppressive $(47,48)$. Additionally, VEGF stimulates the production of interleukin-6 (Il-6) by stroma cells as described in multiple myeloma (49). Since Il-6 is a survival factor for B cells it is possible that expression of VEGF confers a survival advantage for the leukemia cell predisposing to a late relapse. This shows that VEGF might be a potential candidate for therapeutic intervention at least in patients at risk of late relapses. We could not identify any angiogenic markers predisposing for early or very early relapse. This might indicate that other cellular factors are important for determining the fate of more aggressive leukemia subtypes.

A better survival was found for patients expressing higher iNOS mRNA levels in our study. In patients without a relapse the iNOS expression was higher than in relapsing patients, although the difference did not reach statistical significance. The inducible nitric oxide synthase (iNOS) catalyzes the production of endogenous nitric oxide (NO) by the degradation of the amino acid L-arginine in cytokine-activated monocytes, macrophages and NK cells. iNOS was also found in AML (39) and in B-CLL cells (40). NO has tumoricidal and antimicrobial activity in vitro and in vivo (50-52). NO seems to play an important role in tumor cell killing mediated by NK 
and other cells $(53,54)$. Additionally, an inverse correlation between expression of iNOS activity and metastatic behavior was reported in murine melanoma cells $(55,56)$ and transfected human renal carcinoma (57). NO has been associated with angiogenesis in many human tumors $(7,8)$. On the other hand, expression of iNOS has been described to have an antiapoptotic effect on B-CLL cells (40) and in some tumor cell lines to increase chemoresistance (58), possibly by interfering with fas-induced apoptosis (59) and sustaining high bcl-2 levels (60). These contradictory effects of NO have been attributed to different local concentrations of NO (61)). It appears that in the patients in the present study, the association between better prognosis and increased expression of iNOS reflects an increased activity of the NK cell/macrophage system or a decreased tumorigenicity of the leukemia.

In summary, we have found a high expression of TGF- $\beta$ and iNOS, an intermediate expression of VEGF but no expression of bFGF and VEGF-C in bone marrow cells of children with BCP ALL. Differences were seen in the higher expression of VEGF mRNA in patients with late relapses compared to patients without relapses. These findings show that angiogenic factors are expressed in the bone marrow of patients with pediatric ALL and that VEGF might be a potential candidate for therapeutic intervention at least in patients at risk of late relapses since it is preferentially expressed in relapsing patients. An increased expression of iNOS implicated a significantly better prognosis in this pediatric population, possibly reflecting an increased anti-leukemic activity of the immune system. This finding warrants further study to determine the cellular origin of iNOS and the molecular mechanisms of its anti-leukemic activity in childhood BCP ALL.

\section{Acknowledgements}

This study was generously supported by Christina-BergmannStiftung, Munich, Germany.

\section{References}

1. Folkman J: Angiogenesis in cancer, vascular, rheumatoid and other disease. Nat Med 1: 27-31, 1995.

2. Folkman J and D'Amore PA: Blood vessel formation: what is its molecular basis? Cell 87: 1153-1155, 1996.

3. Carmeliet P and Jain RK: Angiogenesis in cancer and other diseases. Nature 407: 249-257, 2000.

4. Folkman J: Seminars in Medicine of the Beth Israel Hospital, Boston. Clinical applications of research on angiogenesis. N Engl J Med 333: 1757-1763, 1995.

5. Plate KH, Breier G, Weich HA and Risau W: Vascular endothelial growth factor is a potential tumour angiogenesis factor in human gliomas in vivo. Nature 359: 845-848, 1992.

6. Pepper MS: Transforming growth factor-beta: vasculogenesis, angiogenesis, and vessel wall integrity. Cytokine Growth Factor Rev 8: 21-43, 1997.

7. Xu W, Liu LZ, Loizidou M, Ahmed M and Charles IG: The role of nitric oxide in cancer. Cell Res 12: 311-320, 2002.

8. Cianchi F, Cortesini C, Fantappie O, et al: Inducible nitric oxide synthase expression in human colorectal cancer: correlation with tumor angiogenesis. Am J Pathol 162: 793-801, 2003.

9. Tischer E, Mitchell R, Hartman T, et al: The human gene for vascular endothelial growth factor. Multiple protein forms are encoded through alternative exon splicing. J Biol Chem 266: 11947-11954, 1991.

10. Klasa RJ, List AF and Cheson BD: Rational approaches to design of therapeutics targeting molecular markers. Hematology (Am Soc Hematol Educ Program): 443-462, 2001.
11. Padro T, Ruiz S, Bieker R, et al: Increased angiogenesis in the bone marrow of patients with acute myeloid leukemia. Blood 95: 2637-2644, 2000.

12. Aguayo A, Estey E, Kantarjian H, et al: Cellular vascular endothelial growth factor is a predictor of outcome in patients with acute myeloid leukemia. Blood 94: 3717-3721, 1999.

13. Aguayo A, Kantarjian H, Manshouri T, et al: Angiogenesis in acute and chronic leukemias and myelodysplastic syndromes. Blood 96: 2240-2245, 2000.

14. Bertolini F, Mancuso P, Gobbi A and Pruneri G: The thin red line: angiogenesis in normal and malignant hematopoiesis. Exp Hematol 28: 993-1000, 2000.

15. Pepper MS, Mandriota SJ, Jeltsch M, Kumar V and Alitalo K: Vascular endothelial growth factor (VEGF)-C synergizes with basic fibroblast growth factor and VEGF in the induction of angiogenesis in vitro and alters endothelial cell extracellular proteolytic activity. J Cell Physiol 177: 439-452, 1998.

16. Dias S, Choy M, Alitalo K and Rafii S: Vascular endothelial growth factor (VEGF)-C signaling through FLT-4 (VEGFR-3) mediates leukemic cell proliferation, survival, and resistance to chemotherapy. Blood 99: 2179-2184, 2002.

17. Toi M, Hoshina S, Takayanagi T and Tominaga T: Association of vascular endothelial growth factor expression with tumor angiogenesis and with early relapse in primary breast cancer. Jpn J Cancer Res 85: 1045-1049, 1994.

18. Takahashi Y, Kitadai Y, Bucana CD, Cleary KR and Ellis LM: Expression of vascular endothelial growth factor and its receptor, KDR, correlates with vascularity, metastasis, and proliferation of human colon cancer. Cancer Res 55: 3964-3968, 1995.

19. Poon RT, Fan ST and Wong J: Clinical implications of circulating angiogenic factors in cancer patients. J Clin Oncol 19: 1207-1225, 2001.

20. Salven P, Teerenhovi L and Joensuu H: A high pretreatment serum vascular endothelial growth factor concentration is associated with poor outcome in non-Hodgkin's lymphoma. Blood 90: 3167-3172, 1997.

21. Salven P, Orpana A, Teerenhovi L and Joensuu H: Simultaneous elevation in the serum concentrations of the angiogenic growth factors VEGF and bFGF is an independent predictor of poor prognosis in non-Hodgkin lymphoma: a single-institution study of 200 patients. Blood 96: 3712-3718, 2000.

22. Molica S, Vitelli G, Levato D, Gandolfo GM and Liso V: Increased serum levels of vascular endothelial growth factor predict risk of progression in early B-cell chronic lymphocytic leukaemia. Br J Haematol 107: 605-610, 1999.

23. Perez-Atayde AR, Sallan SE, Tedrow U, Connors S, Allred E and Folkman J: Spectrum of tumor angiogenesis in the bone marrow of children with acute lymphoblastic leukemia. Am J Pathol 150: 815-821, 1997.

24. Griffioen AW and Molema G: Angiogenesis: potentials for pharmacologic intervention in the treatment of cancer, cardiovascular diseases, and chronic inflammation. Pharmacol Rev 52: 237-268, 2000.

25. Fiedler W, Mesters R, Tinnefeld H, et al: A phase 2 clinical study of SU5416 in patients with refractory acute myeloid leukemia. Blood 102: 2763-2767, 2003.

26. Yang JC, Haworth L, Sherry RM, et al: A randomized trial of bevacizumab, an anti-vascular endothelial growth factor antibody, for metastatic renal cancer. N Engl J Med 349: 427-434, 2003.

27. Motzer RJ, Michaelson MD, Redman BG, et al: Activity of SU11248, a multitargeted inhibitor of vascular endothelial growth factor receptor and platelet-derived growth factor receptor, in patients with metastatic renal cell carcinoma. J Clin Oncol 24: 16-24, 2006.

28. Faivre S, Delbaldo C, Vera K, et al: Safety, pharmacokinetic, and antitumor activity of SU11248, a novel oral multitarget tyrosine kinase inhibitor, in patients with cancer. J Clin Oncol 24: 25-35, 2006.

29. Ribatti D and Vacca A: Novel therapeutic approaches targeting vascular endothelial growth factor and its receptors in haematological malignancies. Curr Cancer Drug Targets 5: 573-578, 2005

30. Hurwitz H, Fehrenbacher L, Novotny W, et al: Bevacizumab plus irinotecan, fluorouracil, and leucovorin for metastatic colorectal cancer. N Engl J Med 350: 2335-2342, 2004.

31. Sparano JA, Gray R, Giantonio B, O'Dwyer P and Comis RL: Evaluating antiangiogenesis agents in the clinic: the Eastern Cooperative Oncology Group Portfolio of Clinical Trials. Clin Cancer Res 10: 1206-1211, 2004. 
32. Harms DO and Janka-Schaub GE: Co-operative study group for childhood acute lymphoblastic leukemia (COALL): long-term follow-up of trials 82, 85, 89 and 92. Leukemia 14: 2234-2239, 2000.

33. Chomczynski P and Sacchi N: Single-step method of RNA isolation by acid guanidinium thiocyanate-phenol-chloroform extraction. Anal Biochem 162: 156-159, 1987.

34. Hussong JW, Rodgers GM and Shami PJ: Evidence of increased angiogenesis in patients with acute myeloid leukemia. Blood 95: 309-313, 2000.

35. Fiedler W, Graeven U, Ergun S, et al: Vascular endothelial growth factor, a possible paracrine growth factor in human acute myeloid leukemia. Blood 89: 1870-1875, 1997.

36. Blobe GC, Schiemann WP and Lodish HF: Role of transforming growth factor beta in human disease. N Engl J Med 342: 1350-1358, 2000

37. Teicher BA: Malignant cells, directors of the malignant process: role of transforming growth factor-beta. Cancer Metastasis Rev 20: $133-143,2001$.

38. Pasche B: Role of transforming growth factor beta in cancer. J Cell Physiol 186: 153-168, 2001.

39. Brandao MM, Soares E, Salles TS and Saad ST: Expression of inducible nitric oxide synthase is increased in acute myeloid leukaemia. Acta Haematol 106: 95-99, 2001.

40. Zhao H, Dugas N, Mathiot C, et al: B-cell chronic lymphocytic leukemia cells express a functional inducible nitric oxide synthase displaying anti-apoptotic activity. Blood 92: 1031-1043, 1998.

41. Lundberg LG, Lerner R, Sundelin P, Rogers R, Folkman J and Palmblad J: Bone marrow in polycythemia vera, chronic myelocytic leukemia, and myelofibrosis has an increased vascularity. Am J Pathol 157: 15-19, 2000.

42. Allouche M, Bayard F, Clamens S, Fillola G, Sie P and Amalric F: Expression of basic fibroblast growth factor (bFGF) and FGF-receptors in human leukemic cells. Leukemia 9: 77-86, 1995.

43. Bellamy WT, Richter L, Frutiger Y and Grogan TM: Expression of vascular endothelial growth factor and its receptors in hematopoietic malignancies. Cancer Res 59: 728-733, 1999.

44. Schulze-Osthoff K, Risau W, Vollmer E and Sorg C: In situ detection of basic fibroblast growth factor by highly specific antibodies. Am J Pathol 137: 85-92, 1990.

45. Fielder W, Graeven U, Ergun S, et al: Expression of FLT4 and its ligand VEGF-C in acute myeloid leukemia. Leukemia 11: 1234-1237, 1997.

46. Salven P, Lymboussaki A, Heikkila P, et al: Vascular endothelial growth factors VEGF-B and VEGF-C are expressed in human tumors. Am J Pathol 153: 103-108, 1998.
47. Gabrilovich DI, Chen HL, Girgis KR, et al: Production of vascular endothelial growth factor by human tumors inhibits the functional maturation of dendritic cells. Nat Med 2: 1096-1103, 1996.

48. Gabrilovich D, Ishida T, Oyama T, et al: Vascular endothelial growth factor inhibits the development of dendritic cells and dramatically affects the differentiation of multiple hematopoietic lineages in vivo. Blood 92: 4150-4166, 1998.

49. Dankbar B, Padro T, Leo R, et al: Vascular endothelial growth factor and interleukin- 6 in paracrine tumor-stromal cell interactions in multiple myeloma. Blood 95: 2630-2636, 2000.

50. Nathan CF and Hibbs JB Jr: Role of nitric oxide synthesis in macrophage antimicrobial activity. Curr Opin Immunol 3: 65-70, 1991.

51. Bogdan C: Nitric oxide and the immune response. Nat Immunol 2: 907-916, 2001

52. Bogdan C, Rollinghoff $M$ and Diefenbach A: The role of nitric oxide in innate immunity. Immunol Rev 173: 17-26, 2000.

53. Li LM, Kilbourn RG, Adams J and Fidler IJ: Role of nitric oxide in lysis of tumor cells by cytokine-activated endothelial cells. Cancer Res 51: 2531-2535, 1991.

54. Jyothi MD and Khar A: Induction of nitric oxide production by natural killer cells: its role in tumor cell death. Nitric Oxide 3 : 409-418, 1999.

55. Dong Z, Staroselsky AH, Qi X, Xie K and Fidler IJ: Inverse correlation between expression of inducible nitric oxide synthase activity and production of metastasis in K-1735 murine melanoma cells. Cancer Res 54: 789-793, 1994.

56. Xie K, Huang S, Dong Z, et al: Transfection with the inducible nitric oxide synthase gene suppresses tumorigenicity and abrogates metastasis by K-1735 murine melanoma cells. J Exp Med 181: 1333-1343, 1995.

57. Juang SH, Xie K, Xu L, et al: Suppression of tumorigenicity and metastasis of human renal carcinoma cells by infection with retroviral vectors harboring the murine inducible nitric oxide synthase gene. Hum Gene Ther 9: 845-854, 1998

58. Yang DI, Yin JH, Mishra S, Mishra R and Hsu CY: NOmediated chemoresistance in C6 glioma cells. Ann NY Acad Sci 962: 8-17, 2002

59. Mannick JB, Miao XQ and Stamler JS: Nitric oxide inhibits Fas-induced apoptosis. J Biol Chem 272: 24125-24128, 1997.

60. Genaro AM, Hortelano S, Alvarez A, Martinez C and Bosca L: Splenic B lymphocyte programmed cell death is prevented by nitric oxide release through mechanisms involving sustained Bcl-2 levels. J Clin Invest 95: 1884-1890, 1995.

61. Dimmeler S and Zeiher AM: Nitric oxide and apoptosis: another paradigm for the double-edged role of nitric oxide. Nitric Oxide 1: 275-281, 1997. 